\section{Cureus}

\title{
Non-Alcoholic Fatty Liver Disease Association with Cardiac Arrhythmias
}

\author{
Muhammad A. Mangi ${ }^{1}$, Hiba Rehman ${ }^{1}$, Abdul M. Minhas ${ }^{2}$, Muhammad Rafique ${ }^{3}$, Vikas \\ Bansal $^{4}$, Jonathan Constantin ${ }^{5}$ \\ 1. GME Internal Medicine, Orange Park Medical Center 2. Internal Medicine, Orange Park Medical Center \\ 3. Anesthesiology, Liaquat National Hospital 4. Critical Care Medicine, Mayo Clinic Jacksonville, Fl 5. \\ Cardiology, Orange Park Medical Center
}

$\square$ Corresponding author: Muhammad A. Mangi,drmasif33@yahoo.com Disclosures can be found in Additional Information at the end of the article

\section{Abstract}

Non-alcoholic fatty liver disease (NAFLD) has become a public health burden all over the world. A significant percentage of the patients with NAFLD have a co-existing metabolic syndrome that is a risk factor for cardiovascular disease. Clinical as well as epidemiological research shows that NAFLD is not simply related to liver-related morbidity and mortality but is also associated with an elevated risk of coronary heart disease (CHD), irregularities of cardiac function as well as cardiac structure, valvular heart disease, and arrhythmias. Animal studies suggest that NAFLD by itself exacerbates systemic/hepatic insulin resistance, leads to atherogenic dyslipidemia and generates a number of pro-inflammatory, pro-coagulant and profibrogenic mediators which play an essential role in the pathophysiology of cardiac abnormalities including arrhythmias. Hence, it is suggested that the patients with NAFLD may derive benefit from intensive monitoring and treatment methods to reduce the risk of CHD along with other cardiac/arrhythmic complications. The intent of this clinical review is to sum up the quickly increasing body of evidence that provides support for a robust relationship between NAFLD and cardiac arrhythmias and to present the putative biological mechanisms underlying this correlation.

Categories: Cardiology, Internal Medicine, Gastroenterology

Keywords: nafld, conduction defects, atrial fibrillation, prolong qtc interval, ventricular arrythmia

\section{Introduction And Background}

Nonalcoholic fatty liver disease (NAFLD) is a fatty infiltration of the liver in the absence of alcohol use or liver infection. NAFLD is a common disorder, affecting almost $30 \%-35 \%$ of the US and western population [1-4]. NAFLD is the third most common indication for the liver

Received 03/30/2017 Review began 04/12/2017 Review ended 04/12/2017 Published 04/13/2017

\section{(c) Copyright 2017}

Mangi et al. This is an open access article distributed under the terms of the Creative Commons Attribution License CC-BY 3.0., which permits unrestricted use, distribution, and reproduction in any medium, provided the original author and source are credited. transplant and is proposed to be the most common cause of end-stage liver disease and liver transplant in the next 10 years [5-6]. The increasing evidence over the past decade suggests that NAFLD is a multisystem disease, it not only damages the liver but also affects the cardiovascular system and causes structural and functional changes in the heart and vessels, leading to increased cardiac-related morbidity and mortality [7-9]. NAFLD is the emerging cause of cardiac arrhythmias. Several arrhythmias are found in association with NAFLD such as atrial fibrillation, QTc (corrected QT) prolongation and ventricular arrhythmias, which can predispose these patients to sudden cardiac death. Here, we provide an extensive literature search of association between NAFLD and various cardiac arrhythmias.

\section{Review}




\section{Association of NAFLD with atrial fibrillation}

Previously, many studies have shown a strong association between NAFLD and coronary heart disease [10-13]. Some studies have also demonstrated fatal and nonfatal cardiovascular events [14-17]. Additional abnormalities include structural changes in the heart and cardiac metabolism [18-22]. Comparatively, fewer studies have evaluated the association of NAFLD with the electrical abnormalities of the heart.

Sinner, et al. analyzed 3,744 adult patients from the Framingham Heart Study and described the association of elevated transaminase level with atrial fibrillation (AF). He found out that the elevated aspartate transaminase (AST) and alanine transaminase (ALT) levels were independently associated with the increased risk of AF over a 10 year follow-up period (Table 1). In this group of the population, they excluded the patients with clinical heart failure [23]. This association was consistent even after adjusting for other risk factors of AF. In an observational study of 702 diabetic patients, Targher, et al. reported a significant association of NAFLD with the prevalence of AF. In this study, NAFLD was diagnosed with the ultrasound (US) [1]. In another study, Targher and colleagues demonstrated that the incidence of AF is high in the patients with NAFLD over a 10 year follow-up period. This association was independent of age, sex, body metabolic index (BMI), and hypertension [24]. Additionally, Karajgmaki, et al. in their prospective study further confirmed the association of NAFLD with AF [25]. 


\section{Cureus}

\begin{tabular}{|c|c|c|c|c|c|c|}
\hline Author & $\begin{array}{l}\text { Year } \\
\text { Published }\end{array}$ & $\begin{array}{l}\text { Study } \\
\text { Design }\end{array}$ & Number of patients & $\begin{array}{l}\text { NAFLD } \\
\text { Diagnosis }\end{array}$ & $\begin{array}{l}\text { Study } \\
\text { Measure }\end{array}$ & Main Findings \\
\hline $\begin{array}{l}\text { Sinner, et } \\
\text { al. [23] }\end{array}$ & 2013 & $\begin{array}{l}\text { Prospective } \\
\text { cohort } \\
\text { study }\end{array}$ & $\begin{array}{l}3744 \text { patients with } \\
\text { no clinical heart } \\
\text { failure (from the } \\
\text { Framingham Heart } \\
\text { Study original and } \\
\text { offspring cohorts) }\end{array}$ & $\begin{array}{l}\text { Liver } \\
\text { enzymes }\end{array}$ & $\begin{array}{l}\text { Incidence } \\
\text { of atrial } \\
\text { fibrillation - } \\
10 \text { years of } \\
\text { follow-up }\end{array}$ & $\begin{array}{l}\text { Elevated transaminases } \\
\text { are independently } \\
\text { associated with the } \\
\text { increased incidence of } \\
\text { atrial fibrillation. }\end{array}$ \\
\hline $\begin{array}{l}\text { Targher, et } \\
\text { al. [1] }\end{array}$ & 2013 & $\begin{array}{l}\text { Cross- } \\
\text { sectional } \\
\text { study }\end{array}$ & $\begin{array}{l}\text { Total: } 702 \text { NAFLD: } \\
514 \text { Non-NAFLD: } \\
188\end{array}$ & Ultrasound & $\begin{array}{l}\text { Prevalence } \\
\text { of } \\
\text { persistent } \\
\text { or } \\
\text { permanent } \\
\text { atrial } \\
\text { fibrillation }\end{array}$ & $\begin{array}{l}\text { NAFLD is associated with } \\
\text { an increased prevalence of } \\
\text { persistent or permanent } \\
\text { atrial fibrillation in patients } \\
\text { with Type } 2 \text { diabetes, } \\
\text { independently of several } \\
\text { clinical risk factors for } \\
\text { atrial fibrillation. }\end{array}$ \\
\hline $\begin{array}{l}\text { Targher, et } \\
\text { al. [24] }\end{array}$ & 2013 & $\begin{array}{l}\text { Prospective } \\
\text { cohort } \\
\text { study }\end{array}$ & $\begin{array}{l}\text { Total: } 400 \text { NAFLD: } \\
281 \text { Non-NAFLD: } \\
119\end{array}$ & Ultrasound & $\begin{array}{l}\text { Incidence } \\
\text { of atrial } \\
\text { fibrillation - } \\
10 \text { years of } \\
\text { follow-up }\end{array}$ & $\begin{array}{l}\text { NAFLD is associated with } \\
\text { the increased incidence of } \\
\text { atrial fibrillation in patients } \\
\text { with type } 2 \text { diabetes even } \\
\text { after adjustment for } \\
\text { important clinical risk } \\
\text { factors for atrial fibrillation. }\end{array}$ \\
\hline $\begin{array}{l}\text { Karajgmaki, } \\
\text { et al. [25] }\end{array}$ & 2015 & $\begin{array}{l}\text { Prospective } \\
\text { cohort } \\
\text { study }\end{array}$ & $\begin{array}{l}\text { Total; } 958 \text { NAFLD: } \\
249 \text { Non-NAFLD: } \\
709\end{array}$ & Ultrasound & $\begin{array}{l}\text { Risk of } \\
\text { atrial } \\
\text { fibrillation - } \\
\text { Mean } \\
\text { follow-up } \\
\text { time was } \\
16.3 \text { years }\end{array}$ & $\begin{array}{l}\text { NAFLD is independently } \\
\text { associated with the } \\
\text { increased risk of atrial } \\
\text { fibrillation. }\end{array}$ \\
\hline
\end{tabular}

\section{TABLE 1: Studies showing association of NAFLD with atrial fibrillation}

NAFLD: non-alcoholic fatty liver disease.

\section{Association of NAFLD with prolonged QTc interval and ventricular arrhythmias}

Research is being done on the association of NAFLD with prolonged QTc interval for the last few years. Liu, et al. showed the presence of cardiac autonomic dysfunction as evident by changes in heart rate variability parameters in the non-diabetic patients with NAFLD [26]. Targher, et al. conducted a study on 460 patients (NAFLD 281, No-NAFLD 179) with diabetes mellitus (DM) to examine the relationship of NAFLD with prolonged QTc (Table 2) [27]. The presence of NAFLD was found to be strongly associated with increased QTc interval. 
Additionally, Hung and colleagues conducted a large cross-sectional study involving 31,116 patients and demonstrated that the severity of NAFLD was associated with higher risk for QTc prolongation in the patients with and without diabetes mellitus (DM) [28]. This association was independent of age, coronary artery disease (CAD), systolic blood pressure (SBP), metabolic syndrome, body metabolic index (BMI), hemoglobin A1c (HbA1c), aspartate transaminase (AST) and estimated glomerular filtration rate (eGFR). A recent retrospective study showed an association of NAFLD with QTc prolongation on univariate analysis (OR 5.09, 95\%CI (2.928.86), p-value < 0.0001) [29]. Motvani, et al. retrospectively analyzed 330 outpatients with type $2 \mathrm{DM}$ without pre-existing atrial fibrillation (AF), end-stage renal disease (ESRD) or liver disorder [30]. These patients underwent 24-hour Holter monitoring (Holter Research Laboratory, Helena Montana, United States) for various clinical reasons. They reported that the patients with NAFLD when compared with the patients without NAFLD, had a higher prevalence of $>30$ premature ventricular contractions (PVCs) per hour, non-sustained ventricular tachycardia (VT) or both. This association remained consistent after adjusting for age, sex, BMI, smoking, chronic kidney disease, chronic obstructive pulmonary disease, ischemic heart disease, valvular heart disease, serum gamma-glutamyl transferase, medication use and ejection fraction. 


\section{Cureus}

\begin{tabular}{|c|c|c|c|c|c|c|}
\hline Author & $\begin{array}{l}\text { Year } \\
\text { Published }\end{array}$ & $\begin{array}{l}\text { Study } \\
\text { Design }\end{array}$ & $\begin{array}{l}\text { Number } \\
\text { of } \\
\text { patients }\end{array}$ & $\begin{array}{l}\text { NAFLD } \\
\text { Diagnosis }\end{array}$ & Study Measure & Main Findings \\
\hline $\begin{array}{l}\text { Targher, et } \\
\text { al. [27] }\end{array}$ & 2014 & $\begin{array}{l}\text { Cross- } \\
\text { sectional } \\
\text { study }\end{array}$ & $\begin{array}{l}\text { Total: } \\
400 \\
\text { NAFLD } \\
281 \\
\text { Non- } \\
\text { NAFLD } \\
179\end{array}$ & Ultrasound & $\begin{array}{l}\text { Prevalence of } \\
\text { prolonged QTc } \\
\text { interval }\end{array}$ & $\begin{array}{l}\text { Presence and severity of NAFLD on } \\
\text { ultrasound are strongly associated } \\
\text { with increased QTc interval in } \\
\text { patients with type } 2 \text { diabetes even } \\
\text { after adjusting for multiple } \\
\text { established risk factors and } \\
\text { potential confounders }\end{array}$ \\
\hline $\begin{array}{l}\text { Hung, et } \\
\text { al. [28] }\end{array}$ & 2015 & $\begin{array}{l}\text { Cross- } \\
\text { sectional } \\
\text { study }\end{array}$ & $\begin{array}{l}\text { Total: } \\
31116 \\
\text { NAFLD: } \\
12891 \\
\text { Non- } \\
\text { NAFLD: } \\
18225\end{array}$ & Ultrasound & $\begin{array}{l}\text { Prevalence of } \\
\text { prolonged QTc } \\
\text { interval }\end{array}$ & $\begin{array}{l}\text { The severity of NAFLD is associated } \\
\text { with a higher risk for QTC } \\
\text { prolongation in the general } \\
\text { population with and without } \\
\text { diabetes }\end{array}$ \\
\hline $\begin{array}{l}\text { Mantovani, } \\
\text { et al. [30] }\end{array}$ & 2016 & $\begin{array}{l}\text { Cross- } \\
\text { sectional } \\
\text { study }\end{array}$ & $\begin{array}{l}\text { Total: } \\
330 \\
\text { NAFLD: } \\
238 \\
\text { Non- } \\
\text { NAFLD: } \\
92\end{array}$ & Ultrasound & $\begin{array}{l}\text { Prevalence of } \\
\text { ventricular } \\
\text { arrhythmias(non- } \\
\text { sustained VT, } \\
\text { >30 PVCs/hour, } \\
\text { or both) }\end{array}$ & $\begin{array}{l}\text { NAFLD is independently associated } \\
\text { with an increased risk of prevalent } \\
\text { ventricular arrhythmias in patients } \\
\text { with type } 2 \text { diabetes }\end{array}$ \\
\hline
\end{tabular}

\section{TABLE 2: Studies showing association of NAFLD with prolonged QTC interval and ventricular arrhythmia}

NAFLD: Non-alcoholic fatty liver disease. PVCs: Premature ventricular contractions. VT: Ventricular tachycardia. QTc: Corrected QT.

\section{Association of NAFLD with conduction defects}

A study conducted to ascertain the relationship of NAFLD with right bundle branch block (RBBB) showed a positive association [31]. The authors of this study postulated that the patients with RBBB are at a higher risk of developing NAFLD due to passive congestion of the liver. A recent retrospective study described the increase prevalence of conduction defects in the patients with NAFLD (OR 2.38, 95\%CI (1.51-3.73), p-value < 0.0001) (Table 3) [29]. The authors of this study postulated that the patients with NAFLD, determined on imaging, are at higher risk of fat deposition in the cardiac muscles and vessels, resulting in the conduction defects. 


\section{Cureus}

\begin{tabular}{|c|c|c|c|c|c|c|}
\hline Author & $\begin{array}{l}\text { Year } \\
\text { Published }\end{array}$ & $\begin{array}{l}\text { Study } \\
\text { Design }\end{array}$ & $\begin{array}{l}\text { Number of } \\
\text { patients }\end{array}$ & $\begin{array}{l}\text { NAFLD } \\
\text { Diagnosis }\end{array}$ & $\begin{array}{l}\text { Study } \\
\text { Measure }\end{array}$ & Main Findings \\
\hline $\begin{array}{l}\text { Işcen, } \\
\text { S. [31] }\end{array}$ & 2013 & $\begin{array}{l}\text { Cross- } \\
\text { sectional } \\
\text { study }\end{array}$ & $\begin{array}{l}\text { Total: } 2200 \\
\text { RBBB: } 220 \text { No- } \\
\text { RBBB: } 1980\end{array}$ & Ultrasound & $\begin{array}{l}\text { Risk of } \\
\text { NAFLD in } \\
\text { RBBB }\end{array}$ & $\begin{array}{l}\text { RBBB is associated with an } \\
\text { increased risk of NAFLD in young } \\
\text { healthy individuals }\end{array}$ \\
\hline $\begin{array}{l}\text { Mangi, } \\
\text { et al. } \\
\text { [29] }\end{array}$ & 2017 & $\begin{array}{l}\text { Case- } \\
\text { control } \\
\text { study }\end{array}$ & $\begin{array}{l}\text { Total; } 700 \\
\text { NAFLD: } 408 \\
\text { Non-NAFLD: } 292\end{array}$ & $\begin{array}{l}\text { Ultrasound, } \\
\text { CT scan of } \\
\text { abdomen }\end{array}$ & $\begin{array}{l}\text { Risk of } \\
\text { conduction } \\
\text { defects }\end{array}$ & $\begin{array}{l}\text { NAFLD is associated with } \\
\text { conduction defects }\end{array}$ \\
\hline
\end{tabular}

TABLE 3: Studies showing association of NAFLD with conduction defect

RBBB: Right bundle branch block. NAFLD: Non-alcoholic fatty liver disease.

\section{Mechanism of NAFLD causing cardiac arrhythmias}

The mechanism of NAFLD association with cardiovascular disease (CVD) is not well known, but various hypotheses have been generated for the possible pathogenesis of CVD in the patients with NAFLD. It is debatable if NAFLD is a mere risk marker for the development of CVD or NAFLD is the direct contributor to the development of the disease. Initially, it was thought that the association between NAFLD and CVD/arrhythmias might be due to the fact that they share common risk factors, but more and more studies are being done which show their relation independent of these confounders. It is difficult to unwind this complex relationship as NAFLD and CVD share similar risk factors. NAFLD might be a marker for ectopic fat deposition in myocardium and pericardium. These structural heart changes predispose to cardiovascular events. Previously, a study has shown an association between intrahepatic and myocardial triacylglycerol content and that increased pericardial fat is associated with increased prevalence of atrial fibrillation [32-33]. Experiments have also revealed that adipocytes in retrosternal, epicardial tissue can exert effects on ion currents in rabbit left atria, leading to arrhythmias and other complications [34]. However, it has been hypothesized that NAFLD directly contributes to the development of cardiovascular complications. For instance, it has been proposed that NAFLD is associated with increased production of pro-inflammatory cytokines ( $\mathrm{C}$ - reactive protein, interleukin - 6 and tumor necrosis factor - alpha), prothrombotic factors (fibrinogen, factor VIII, plasminogen activator inhibitor -1) [35-38]. These markers have been shown to be associated with increased cardiac structural and arrhythmogenic complications, possibly by cardiac structural and electrical remodeling [39-41].

\section{Treatment of NAFLD}

NAFLD is being seen as one of the important risk factors for cardiovascular morbidity and mortality [42-43]. It is plausible that the health care provider should treat the patients with NAFLD aggressively to decrease cardiovascular morbidity and mortality. The lifestyle modifications, including weight loss, dietary modifications, and physical activity are the first line treatment for NAFLD and have shown to improve the outcomes [44-45]. The patients should be given pharmacotherapy if nonalcoholic steatohepatitis (NASH) is present [46]. Treatment of DM, hyperlipidemia, and obesity not only improve the hepatic histology but also improve the cardiovascular outcomes [47]. Concurrent management of hypertension does not have a major impact on liver histology but improves cardiovascular morbidity [47]. Additionally, thiazolidinediones (pioglitazone and rosiglitazone) and liraglutide are approved for the management of NAFLD [48-49]. 


\section{Conclusions}

The role of NAFLD in cardiovascular complications has been extensively researched. Previous studies have shown the association of NAFLD with cardiac structural, metabolic and functional changes. Fewer studies have been conducted on the association with cardiac arrhythmias. These studies have shown that NAFLD has arrhythmogenic potential which requires further testing and confirmation. The pathophysiological mechanism of NAFLD is not very well understood. More research is needed to establish the pathways that are involved in the development of cardiovascular complications. We believe that NAFLD is a promising field of research to explore the pathways involved in the causation of arrhythmias that could possibly provide a therapeutic target for treatment and help in the prevention of cardiac remodeling and electrophysiological abnormalities.

\section{Additional Information}

\section{Disclosures}

Conflicts of interest: In compliance with the ICMJE uniform disclosure form, all authors declare the following: Payment/services info: All authors have declared that no financial support was received from any organization for the submitted work. Financial relationships: All authors have declared that they have no financial relationships at present or within the previous three years with any organizations that might have an interest in the submitted work. Other relationships: All authors have declared that there are no other relationships or activities that could appear to have influenced the submitted work.

\section{References}

1. Targher G, Mantovani A, Pichiri I, et al.: Non-alcoholic fatty liver disease is associated with an increased prevalence of atrial fibrillation in hospitalized patients with type 2 diabetes. Clin Sci. 2013, 125:301-309. 10.1042/CS20130036

2. Clark JM, Brancati FL, Diehl AM: The prevalence and etiology of elevated aminotransferase levels in the United States. Am J Gastroenterol. 2003, 98:960-967. 10.1111/j.15720241.2003.07486.x

3. Chalasani N, Younossi Z, Lavine JE, et al.: The diagnosis and management of non-alcoholic fatty liver disease: practice Guideline by the American Association for the Study of Liver Diseases, American College of Gastroenterology, and the American Gastroenterological Association. Hepatology. 2012, 55:2005-2023. 10.1002/hep.25762

4. Browning JD, Szczepaniak LS, Dobbins R, et al.: Prevalence of hepatic steatosis in an urban population in the United States: impact of ethnicity. Hepatology. 2004, 40:1387-1395. 10.1002/hep.20466

5. Nascimbeni F, Pais R, Bellentani S, et al.: From NAFLD in clinical practice to answers from guidelines. J Hepatol. 2013, 59:859-871. 10.1016/j.jhep.2013.05.044

6. Lonardo A, Bellentani S, Argo CK, et al.: Epidemiological modifiers of non-alcoholic fatty liver disease: focus on high-risk groups. Dig Liver Dis. 2015, 47:997-1006. 10.1016/j.dld.2015.08.004

7. Byrne CD, Targher G: NAFLD: a multisystem disease . J Hepatol. 2015, 62:47-64. 10.1016/j.jhep.2014.12.012

8. Armstrong MJ, Adams LA, Canbay A, et al.: Extrahepatic complications of nonalcoholic fatty liver. Hepatology. 2014, 59:1174-1197. 10.1002/hep.26717

9. Markus MR, Baumeister SE, Stritzke J, et al.: Hepatic steatosis is associated with aortic valve sclerosis in the general population: the Study of Health in Pomerania (SHIP). Arterioscler Thromb Vasc Biol. 2013, 33:1690-1695. 10.1161/ATVBAHA.112.300556

10. Lin YC, Lo HM, Chen JD: Sonographic fatty liver, overweight and ischemic heart disease . World J Gastroenterol. 2005, 11:4838-4842. 10.3748/wjg.v11.i31.4838

11. Targher G, Bertolini L, Padovani R, et al.: Prevalence of nonalcoholic fatty liver disease and its association with cardiovascular disease among type 2 diabetic patients. Diabetes Care. 2007, 30:1212-8. 10.2337/dc06-2247 
12. Arslan U, Türkoğlu S, Balcioğlu S, et al.: Association between nonalcoholic fatty liver disease and coronary artery disease. Coron Artery Dis. 2007, 18:433-436.

10.1097/MCA.0b013e3282583c0d

13. Mirbagheri SA, Rashidi A, Abdi S, et al.: Liver: an alarm for the heart? Liver Int. 2007, 27:891894. 10.1111/j.1478-3231.2007.01531.x

14. Dunn W, Xu R, Wingard DL, et al.: Suspected nonalcoholic fatty liver disease and mortality risk in a population-based cohort study NAFLD and mortality risk. Am J Gastroenterol. 2008, 103:2263-2271. 10.1111/j.1572-0241.2008.02034.x

15. Ong JP, Pitts A, Younossi ZM: Increased overall mortality and liver-related mortality in nonalcoholic fatty liver disease. J Hepatol. 2008, 49:608-612. 10.1016/j.jhep.2008.06.018

16. Lerchbaum E, Pilz S, Grammer TB, et al.: The fatty liver index is associated with increased mortality in subjects referred to coronary angiography. Nutr Metab Cardiovasc Dis. 2013, 23:1231-1238. 10.1016/j.numecd.2013.02.004

17. Jepsen P, Vilstrup H, Mellemkjaer L, et al.: Prognosis of patients with a diagnosis of fatty liver-a registry-based cohort study. Hepatogastroenterology. 2003, 50:2101-2104.

18. Goland S, Shimoni S, Zornitzki T, et al.: Cardiac abnormalities as a new manifestation of nonalcoholic fatty liver disease: echocardiographic and tissue Doppler imaging assessment. J Clin Gastroenterol. 2006, 40:949-955. 10.1097/01.mcg.0000225668.53673.e6

19. Fallo F, Dalla Pozza A, Sonino N, et al.: Non-alcoholic fatty liver disease is associated with left ventricular diastolic dysfunction in essential hypertension. Nutr Metab Cardiovasc Dis. 2009, 19:646-653. 10.1016/j.numecd.2008.12.007

20. Fotbolcu H, Yakar T, Duman D, et al.: Impairment of the left ventricular systolic and diastolic function in patients with non-alcoholic fatty liver disease. Cardiol J. 2010, 17:457-463.

21. Mantovani A, Zoppini G, Targher G, et al.: Non-alcoholic fatty liver disease is independently associated with left ventricular hypertrophy in hypertensive Type 2 diabetic individuals. J Endocrinol Invest. 2012, 35:215-218. 10.1007/BF03345421

22. Perseghin G, Lattuada G, De Cobelli F, et al.: Increased mediastinal fat and impaired left ventricular energy metabolism in young men with newly found fatty liver. Hepatology. 2008, 47:51-58. 10.1002/hep.21983

23. Sinner MF, Wang N, Fox CS, et al.: Relation of circulating liver transaminase concentrations to risk of new-onset atrial fibrillation. Am J Cardiol. 2013, 111:219-224.

10.1016/j.amjcard.2012.09.021

24. Targher G, Valbusa F, Bonapace S, et al.: Non-alcoholic fatty liver disease is associated with an increased incidence of atrial fibrillation in patients with type 2 diabetes. PLoS One. 2013, 8:10.1371/journal.pone.0057183

25. Aki J. Käräjämäki, Olli-Pekka Pätsi, et al.: Non-Alcoholic Fatty Liver Disease as a Predictor of Atrial Fibrillation in Middle-Aged Population (OPERA Study). PLoS One. 2015, 10:10.1371/journal.pone.0142937

26. Liu YC, Hung CS, Wu YW, et al.: Influence of non-alcoholic fatty liver disease on autonomic changes evaluated by the time domain, frequency domain, and symbolic dynamics of heart rate variability. PLoS One. 2013, 8:10.1371/journal.pone.0061803

27. Targher G, Valbusa F, Bonapace S, et al.: Association of nonalcoholic fatty liver disease with QTc interval in patients with type 2 diabetes. Nutr Metab Cardiovasc Dis. 2014, 24:663-9. 10.1016/j.numecd.2014.01.005

28. Hung CS, Tseng PH, Tu CH, et al.: Nonalcoholic fatty liver disease is associated with qt prolongation in the general population. J Am Heart Assoc. 2015, 4:e01820.

10.1161/JAHA.115.001820

29. Mangi MA, Minhas AM, Rehman H, et al.: Association of non-alcoholic fatty liver disease with conduction defects on electrocardiogram. Cureus. 2017, 9:1107. 10.7759/cureus.1107

30. Mantovani A, Rigamonti A, Bonapace S, et al.: Nonalcoholic fatty liver disease is associated with ventricular arrhythmias in patients with type 2 diabetes referred for clinically indicated 24-hour Holter monitoring. Diabetes Care. 2016, 39:1416-23. 10.2337/dc16-0091

31. İşcen S: RBBB is associated with an increased risk of NAFLD in young healthy individuals . Int J Cardiol. 2013, 168:4056-4057. 10.1016/j.ijcard.2013.07.035

32. Rijzewijk LJ, van der Meer RW, Smit JW, et al.: Myocardial steatosis is an independent predictor of diastolic dysfunction in type 2 diabetes mellitus. J Am Coll Cardiol. 2008, 52:1793-1799. 10.1016/j.jacc.2008.07.062

33. Thanassoulis G, Massaro JM, O'Donnell CJ, et al.: Pericardial fat is associated with prevalent 
atrial fibrillation: the Framingham Heart Study. Circ Arrhythm Electrophysiol. 2010, 3:345350. 10.1161/CIRCEP.109.912055

34. Lin YK, Chen YC, Chen JH, et al.: Adipocytes modulate the electrophysiology of atrial myocytes: implications in obesity-induced atrial fibrillation. Basic Res Cardiol. 2012, 107:293. 10.1007/s00395-012-0293-1

35. Anstee QM, Targher G, Day CP: Progression of NAFLD to diabetes mellitus, cardiovascular disease or cirrhosis. Nat Rev Gastroenterol Hepatol. 2013, 10:330-344.

10.1038/nrgastro.2013.41

36. Targher G, Day CP, Bonora E: Risk of cardiovascular disease in patients with nonalcoholic fatty liver disease. N Engl J Med. 2010, 363:1341-1350. 10.1056/NEJMra0912063

37. Bhatia LS, Curzen NP, Calder PC, et al.: Non-alcoholic fatty liver disease: a new and important cardiovascular risk factor?. Eur Heart J. 2012, 33:1190-200. 10.1093/eurheartj/ehr453

38. Targher G, Byrne CD: Nonalcoholic fatty liver disease: a novel cardiometabolic risk factor for type 2 diabetes and its complications. J Clin Endocrinol Metab. 2013, 98:483-495.

10.1210/jc.2012-3093

39. Chung MK, Martin DO, Sprecher D, et al.: C-reactive protein elevation in patients with atrial arrhythmias: inflammatory mechanisms and persistence of atrial fibrillation. Circulation. 2001, 104:2886-2891.

40. Aviles RJ, Martin DO, Apperson-Hansen C, et al.: Inflammation as a risk factor for atrial fibrillation. Circulation. 2003, 108:3006-3010. 10.1161/01.CIR.0000103131.70301.4F

41. Guo Y, Lip GY, Apostolakis S: Inflammation in atrial fibrillation. J Am Coll Cardiol. 2012, 60:2263-2270. 10.1016/j.jacc.2012.04.063

42. Younossi ZM1, Otgonsuren M, Venkatesan C, et al.: In patients with non-alcoholic fatty liver disease, metabolically abnormal individuals are at a higher risk for mortality while metabolically normal individuals are not. Metabolism. 2013, 62:352-360. 10.1016/j.metabol.2012.08.005

43. Rafiq N, Bai C, Fang Y, et al.: Long-term follow-up of patients with nonalcoholic fatty liver . Clin Gastroenterol Hepatol. 2009, 7:234-238. 10.1016/j.cgh.2008.11.005

44. Ratziu V, Bellentani S, Cortez-Pinto H, et al.: A position statement on NAFLD/NASH based on the EASL 2009 special conference. J Hepatol. 2010, 53:372-384. 10.1016/j.jhep.2010.04.008

45. Loria P, Adinolfi LE, Bellentani S, et al.: Practice guidelines for the diagnosis and management of nonalcoholic fatty liver disease. A decalogue from the Italian Association for the Study of the Liver (AISF) Expert Committee. Dig Liver Dis. 2010, 42:272-282. 10.1016/j.dld.2010.01.021

46. Ballestri S, Lonardo A, Bonapace S, et al.: Risk of cardiovascular, cardiac and arrhythmic complications in patients with non-alcoholic fatty liver disease. World J Gastroenterol. 2014, 20:1724-1745. 10.3748/wjg.v20.i7.1724

47. Misra VL, Khashab M, Chalasani N: Non-alcoholic fatty liver disease and cardiovascular risk . Curr Gastroenterol Rep. 2009, 11:50-55.

48. Belfort R, Harrison SA, Brown K, et al.: A placebo-controlled trial of pioglitazone in subjects with nonalcoholic steatohepatitis. N Engl J Med. 2006, 355:2297-2307. 10.1056/NEJMoa060326

49. Armstrong MJ, Gaunt P, Aithal GP, et al.: Liraglutide safety and efficacy in patients with nonalcoholic steatohepatitis (LEAN): a multicentre, double-blind, randomised, placebo-controlled phase 2 study. Lancet. 2016, 387:679-690. 10.1016/S0140-6736(15)00803-X 